\title{
Chapter 4 \\ Land Plots with Unknown Owners: Causes and Legal Measures-The Necessity for a Thorough Reduction of Transaction Costs
}

\section{Hideo Fukui}

\begin{abstract}
The increase of land plots with unknown owners, namely, land plots whose owner's name and address are not easily identifiable through repeated inheritance, etc., has emerged as a prominent social issue. The major reason for this phenomenon is the Civil Code that unconditionally allows the sharing of real estate by an unlimited number of co-owners, for one thing, and the registration system of real estate that does not require the true owner to register and thus does not show the real rights of real estate, for another. To reduce the increase of land plots with unknown owners as a proactive measure and to utilize them as a reactive measure, it is necessary to establish the one-owner principle with a ban of the sharing of real estate even through inheritance, to abolish fixed asset tax on buildings and houses, to require the new owner of real estate to register the right upon the transfer of ownership and for the registration office to make it public, to amend the Land Expropriation Act to facilitate the purchase of the land plots for public purpose without owner identification, to create an institutional arrangement that allows the will of the owner to be fictionally replaced, and to amend the Civil Code to allow the disposal of shared real estate by the majority of the co-owners.
\end{abstract}

Keywords Real estate - Unknown owners · Registration · Inheritance · Transaction cost $\cdot$ Civil Code

\subsection{Why Is There Land with Unknown Ownership?}

There has been a considerable increase in the number of problematic cases caused by a landowner being unknown, or unreachable if known, as in the case of land acquisition for public use. This has led to discussion at various levels concerning

\footnotetext{
H. Fukui ( $\triangle)$

National Graduate Institute for Policy Studies, Tokyo, Japan

e-mail: fukui@grips.ac.jp

(C) The Author(s) 2021

Y. Asami et al. (eds.), Frontiers of Real Estate Science in Japan, New Frontiers in

Regional Science: Asian Perspectives 29,

https://doi.org/10.1007/978-981-15-8848-8_4
} 
the causes and solutions. ${ }^{1}$ In particular, there are cases with successive inheritance of land that should have resulted in co-ownership among multiple heirs, yet because of the complete lack of update in registration, the land remains registered in the name of the Meiji era owner. An enormous amount of time and effort has to be expended to search for and acquire ownership when land is required for public purposes.

In many cases where the usage value does not warrant an enormous burden, such as the situation wherein there is acquisition or intended use by the private sector, the land remains underutilized for a long period without a transfer of ownership or an establishment of the usage rights. The causes of such cases are investigated below.

\subsubsection{The State of Shared Ownership That Tends to Arise Through the Ownership and Inheritance Provisions in the Civil Code}

Successive inheritance and transition without discussion about the split of inherited property lead to land and buildings remaining in a state of co-ownership in perpetuity. Subsequently, mutual discussion and arrangements for management of the land and buildings become practically impossible. Unless there is a transition to special procedures such as the determination proceeding for unknown ownership under the Expropriation Act, the relationship of rights and the physical form of land use will be effectively frozen regardless of the reasonable intent of the relevant parties or the most effective utilization of the land.

The fundamental cause is considered to be the ownership and inheritance provisions under the Civil Code that enable a state of shared ownership for land and buildings for which it is difficult to reconcile the rights.

The "state of shared ownership" is an exception to the Civil Code's official principle of sole ownership, so the Civil Code views it as a temporary situation that requires resolution as quickly as possible with restoration to sole ownership. Therefore, "the freedom to split common property and transfer the owner's interests is granted to each co-owner." ${ }^{2}$ However, a transfer requires an agreement of intent of relevant parties. In a typical case of a problem of land with unknown ownership, the person who should express the intent is often unknown, and the transfer of interest does not function. In addition, this does not work when splitting common property in the case of a building because a building will not qualify for sole ownership unless

\footnotetext{
${ }^{1}$ National Land Planning Association "Working Group on the Problem of Land with Unknown Ownership (Chairman, Hiroya Masuda)" http://www.kok.or. jp/project/fumei.html, Ministry of Land, Infrastructure, Transport, and Tourism, the National Land Council, http://www.mlit.go. jp/policy/shingikai/s101_kokudo01.html, Japan Association of Real Estate Sciences, The Association of Urban Housing Sciences, The Japan Association for Property Assessment Policy "Working Group on Land with Unknown Ownership (Chairman, Masaaki Iwasaki)," etc.

${ }^{2}$ Suzuki (2007) page 41.
} 
special circumstances exist, as in the case wherein the building comprises individual units that can be split. Even in the case of land, various matters are prescribed, including access regulations, size of site regulations, overshadowing regulations, building coverage ratio, and floor area ratio regulations according to specific public regulations such as urban planning and building regulations. Therefore, there are many circumstances where it is actually difficult to protect the asset value through sole ownership by splitting it. Hence, this method cannot always be said to work. Furthermore, where multiple co-owners already exist, it is often the case that the interests belonging to the identified co-owners are very small, and the object of sole ownership has no significance.

The co-ownership of land and buildings is, in principle, possible under the Civil Code, but the consent of other co-owners is required if any of the co-owners wishes to make an alteration to such properties (Article 251 of the Civil Code). This "alteration" includes acts of disposal such as sales, so the property cannot be sold without the consent of all co-owners. ${ }^{3}$

Furthermore, under the current inheritance law, land and buildings will be co-owned in accordance with the legally inherited portions unless a settlement is made about inheritance split at the time of inheritance. However, inheritance specialists strongly recommend avoiding co-ownership of inherited land and buildings. This is because it is difficult to reconcile the rights, even those of relatives, of co-ownership of land and buildings as the settlement has to abide by the rules in the rights of ownership of the Civil Code. This reduces the profits that can be generated from the land and is highly likely to impede the effective utilization of the land.

Even in the case of inheritance, the inherited land and building will automatically be subject to discussion about inheritance split unless there is a will. Disputes between relatives concerning such inheritance are common. Even if there is a desire on the part of a child who has been a long-term resident living with the person who dies, to inherit a residence, unless the discussion about inheritance split is successfully completed, such child must either purchase the interests of other heirs or sell the residence and distribute the proceeds according to the proportion of legal inheritance when there are other heirs. Agreement is not always possible. In such cases, the current inheritance law is contrary to the intent of the Civil Code. If anything, the principle is the co-ownership of land and buildings through the legal division of inheritance; the structure only allows for the approval of a sole owner in the exceptional case that agreement is achieved.

However, where there has been successive inheritance and extreme fragmentation of the rights for land and buildings, enormous transaction costs can be incurred in reconciling the rights to achieve a unanimous decision of all heirs to sell; it is

\footnotetext{
${ }^{3}$ By contrast, in accordance with Article 252 of the Civil Code, management actions such as certain leases may be determined by co-owners holding a majority of the value of the shares, but it is difficult to arrange the discussion itself when there has been successive inheritance and the co-owners holding the majority are hard to identify.
} 
effectively impossible. Therefore, the appearance of an intricate state of shared ownership ultimately results in the unconditional release of such real estate based on the ownership law under the Civil Code and the inheritance law that unconditionally approves inheritance with various fragmented co-ownership rights themselves being considered the source of the problem.

\subsubsection{Real Estate Registration has Little Benefit Despite the High Cost}

Currently, Japanese real estate registration is merely a perfection requirement (Article 177 of the Civil Code), and it is irrelevant for the efficacy of ownership transfer. There is also no obligation for registration. Therefore, registration cannot be said to show the true relationship of rights, yet there is also no other system providing public notice of the true owner. The title deed holder of the land and building in the registry often does not reflect the true owner.

In addition, registration procedures are not necessarily easy for an ordinary person and require a certain degree of specialist knowledge as well as time. Furthermore, real estate registration tax due to titling is, in principle, $2 \%$ of the price recorded on the normal fixed asset tax register such as the ownership transfer title. Such amount greatly exceeds the substantive intent of the titling fee. When this cost and the fee payable to specialists (e.g., judicial scriveners) are calculated, in cases where each individual ownership transfer does not require registration, a middle omission registration (i.e., registration of only the initial and final owners and omission of the rest), which saves on the inconvenience and the cost, is widely used to avoid the high costs that are levied regardless of the low benefits of titling. ${ }^{4}$

In conjunction with this, apart from when the land has an exceptionally high asset value, the title has little benefit and incurs a large cost in many cases, so the individual registration of ownership transfers is unlikely. The continuation of such practice has exacerbated the state of owners being unknown, making effective use more difficult. Land such as urban residential land with high usage value is being identified, even at a cost, and is fluidized. However, there is little benefit in having a title for areas on the outskirts of cities and rural and/or mountainous districts, resulting in a tendency for the title on such properties not to reflect the true owner. The relative merit of effective utilization gradually ceases to be worth the cost.

\footnotetext{
${ }^{4}$ Fukui and Yoshida (2008) pages 8 to 25.
} 


\subsubsection{The High Cost of Land Fixed Assets Tax Means It Is Not Worth the Usage Value}

The fixed assets tax on land is, in principle, levied every year at a rate of $1.4 \%$ of the market value (Article 350, paragraph (1) of the Local Tax Act). Detailed provisions of the basis for the valuation of fixed assets and procedures, etc., are in Article 388 and the following articles of the Local Tax Act. However, apart from disputes on the valuation of fixed assets when land prices have fallen, with tax based on appraisal values higher than actual market values, it is observed that there have been high valuations on land with little marketability in regional areas where it has been hard to estimate a real transaction price because of a virtual lack of actual transactions. The fixed assets tax levied on land ownership functions as the payment for the benefits of public service and public welfare facilities that belong to the land, including roads, water, and sewer services as well as public parks. In this regard, the fixed assets tax is intended to cover the cost burden for usage fees that are difficult to collect, for so-called public goods (i.e., goods for which simultaneous consumption is possible and the exclusion of any given user is difficult) or for facilities that provide special benefits to land owners owing to the location of the land, even if usage fees could be collected. That is, this entails a request to cover the costs of facilities with positive externalities (benefits to persons other than the relevant transaction parties).

Landholding tax inherently reduces profit and the price of land. However, as long as the tax amount is commensurate with the benefits of services received in this manner, it does not inhibit the effective utilization of land and secures financial resources. As long as such resources are invested appropriately, it also promotes the effective utilization of land. However, were there a high tax burden that was not commensurate with the utilization value, as in the case wherein tax is based on the appraisal value that is constantly higher than the actual price, the price of land would fall in proportion to such a tax burden. If the tax burden exceeds the expected profit, owning land would become disadvantageous and a rational choice would be to dispose of such land. However, few people are likely to keep or take such land not to mention that the national and local governments will not accept the donation of such land. The incentives for land use gradually dwindle because of distorted taxes that do not match the value of the asset, and there is a tendency for ownership to become unknown through successive inheritance. 


\subsubsection{This Fixed Assets Tax on Buildings Does Not Function as the Beneficiary's Burden in Relation to Public Service and Public Welfare Facilities}

This is because the externalities of these facilities are only reflected in the value of the land and are irrelevant for building values. ${ }^{5}$ In addition, since the tax on buildings always increases the burden on the effective utilization of land by way of construction activities, it functions as a tax system that inhibits investment and is always negative for the effective utilization of land.

Furthermore, by taxing at the "market value" of the building under the Japanese valuation of fixed assets standard, buildings with high earthquake resistance properties that are solid, safe, and better for the environment pay a higher amount of tax than other buildings even if the floor space is the same. In other words, the system provides preferential treatment for buildings that are dangerous and weak and that have poor environmental performance and habitability.

In this regard, the fixed assets tax on buildings is always an impediment to the utilization of land. Since this is an impediment to investment in quality safe buildings in particular, it promotes land becoming vacant and contributes to the situation of unknown ownership.

\subsubsection{Distortion in Inheritance Tax Assessment}

Depreciation of a land lot with a building and depreciation of rental houses in the inheritance tax assessment distort the neutrality of land use. Moreover, it is an obstruction to the effective utilization of land. The recently discussed vacant house problem, in particular, is the problem of keeping, not scrapping, the buildings which are not only degraded and unusable but of negative externalities such as the danger to the neighboring areas with fire and collapse, deterioration of the aerial environment with insects, dust, exuberant plants, and uncomfortable landscape. However, one of the main causes of obstruction to effective utilization is the favorable treatment under the tax system for the retention of buildings in the assessment of inheritance tax. Having a vacant land lot is disadvantageous while waiting for inheritance, and

\footnotetext{
${ }^{5}$ Fukui (1999) argues that the convenience of location and environmental factors should all be considered for the land valuation only in relation to loss compensation for land expropriation. This is because they do not belong to the building and should not be assumed to have an impact on the building for the reason that other factors, such as the value of the view for a compartmentalized ownership building, should be considered as the rights of the interests of all co-owners of the land and therefore not part of the evaluation of the building. Factors other than those that have physical value, such as the materials, equipment, and structure of the building, assume the possibility that the house can be moved as is as well as dismantled and relocated.
} 
retaining even a poor quality building without demolishing it becomes the logical choice for landowners.

In any event, the favorable treatment of a land lot with a building regardless of its quality under the inheritance tax assessment means even the land that should have renewed land use tends to be left with buildings of inefficiency. Moreover, because the motive of land use is to deal with inheritance tax, such treatment promotes the state of unknown ownership occurring through inheritance. To begin with, inconsistency emerges since the fixed assets tax on buildings is negative for investment in high-quality buildings while inheritance tax provides favorable treatment in relation to the retention of low quality buildings.

\subsection{Land with Unknown Ownership as a Problem of Transaction Costs: The High Cost of Reconciling Rights Is an Obstacle to Land Use}

As noted above, various factors contribute to unknown ownership, including several artificial and systemic factors. These factors contribute to the decline in incentive for the owner himself or herself to use the land and make it difficult to find an interested buyer. Furthermore, once there is shared ownership due to inheritance, for example, it exacerbates the difficulties of using the land in what becomes a negative spiral. Once the number of co-owners exceeds a certain threshold, the cost of reconciling the rights becomes extremely large, resulting in the cessation of future transactions and land use. Consequently, the names and whereabouts of many co-owners become increasingly unknown. Therefore, the certainty of the current method of use for such land is virtually limited to the cases in which determination proceeding is applied without identifying the owner's name or address for business with broad expropriation rights such as businesses that just happen to be qualified for expropriation as well as land readjustment projects under the Expropriation Act and urban area redevelopment projects.

In and of itself, if the ownership right is clearly described and if the transfer is freely made and no cost is incurred on such transfer, such land would always be used effectively regardless of the owner. This is Coase's theorem. ${ }^{6}$

The assumptions of Coase's theorem do not necessarily always correspond to the real world, but determining the rules for methods concerning ownership that come close to such assumptions would function as a method to promote the constant effective utilization of land.

\footnotetext{
${ }^{6}$ Fukui (2007), pages 72 to 73 , discusses the rights concerning running water from rivers and the rights to an injunction concerning environment pollution in pages 235 to 245 adding analysis from the perspectives of Coase's theorem and transaction cost, respectively. Fukui (2001) discusses land use regulation and public legal regulation from the perspective of Coase's theorem.
} 
The important implications from Coase's theorem are as follows. First, the law should prescribe the details of rights clearly and simply. Second, the law should prescribe procedures such as the administration of justice and administration to minimize the transaction costs, including those for the adjustment of rights, as much as possible. Third, the law should allocate rights, such as the initial ownership rights, to the side that has the lowest sum total of ex-post-facto transaction costs so that the transfer of rights can proceed as smoothly as possible through negotiation with the ex-post-fact relevant parties. ${ }^{7}$

From this perspective, even if co-ownership is positioned as "temporary," the following facts are contrary to the theorem's first implication: first, that co-ownership is, in actuality, allowed and the ownership law in the Civil Code is a structure with readily growing complications that inevitably require large adjustment of rights for the procedures and management of co-owned land and second, that the inheritance law does not have a special level of interest regarding real estate co-ownership and easily allows co-ownership

As noted later, the determination proceedings for unknown ownership in the case of land expropriation are a major burden for expropriators, whereas expropriation procedures cannot be dealt with easily or with speed.

There could be certain possible measures for private sector businesses such as those via the system of administration of absentee property (from Article 25 of the Civil Code) and the administration system for inherited property (from Article 951 of the Civil Code), but there are constraints on the act of disposal in such cases. In addition, where it is not known if the heir is alive or such person's address is unknown, the latter does not apply, and it is virtually impossible for a private sector business to purchase land with unknown ownership.

In this regard, from the perspective of the smooth transfer of rights, there are major constraints on the decision-making by the relevant party or the alternative decision-making by the relevant party to undertake an act of disposal as a right under existing law, which is also contrary to the second implication above. For the allotment of the initial rights, the scheme tends to assume multiple co-owners and not a sole owner, which is also contrary to the third implication of Coase's theorem above.

It is no exaggeration to state that the problem of land with unknown ownership is a product of a legal system that tends to artificially create high cost for reconciling rights. How to reduce such transaction costs as much as possible should be taken to task. In this case, there needs to be a transition to processing methods assuming unknown ownerships. However, if the legal system that tends to create neglected unknown ownership remains as is and the ex-post-facto transactions costs are kept intentionally high, the effort required for such process is quite unreasonable.

Therefore, in addition to measures for the effective utilization of land with unknown ownership, it is imperative to have preventive measures so that it becomes difficult for land with unknown ownership to exist in the first place.

\footnotetext{
${ }^{7}$ Fukui (2007) pages 238 to 239.
} 


\subsection{Fixed Assets Tax on Land and Buildings, Land Capital Gains Tax, and Land Liquidity}

Further detailed consideration is made concerning the aforementioned problem of tax on land and buildings.

\subsubsection{Land Tax}

The fixed assets tax on co-owned land is a joint obligation of all the owners (Article 10-2 of the Local Tax Act). In practice, it is often the case that the local government bodies in regional areas issue the request to an appropriately prescribed representative. Fixed assets tax cannot be avoided unless the evaluation is below a certain tax exemption threshold, even if the land has no actual usage value and even when it is difficult to reconcile the rights. Conversely, the land transfer tax is not levied even if there is a transfer as long as there is no profit on the transfer.

For fixed assets tax, the appropriate tax rate that applies to the market value, or, in other words, anticipated usage value in the market, means that the tax burden on land with low usage value should be small, yet in actuality, a high amount of tax is often levied. ${ }^{8}$

Were fixed assets tax levied in excess of the profit value of the land, the land itself would become a negative asset. If the tax is higher than the profit from the effective utilization of land, it is better not to own the land. If it is not permitted to renounce ownership of this type of land during the owner's lifetime, it becomes increasingly likely that an heir will renounce the inheritance at the time of inheritance.

In addition, even if the fixed assets tax is lower than the profit value of the land, the benefit of the land will similarly disappear if tax accounts for a large proportion of the profit. The higher the level of tax relative to the profit value, the lower the market price of the land.

Furthermore, when agreement of all co-owners is, in practical terms, impossible, the land cannot be disposed of as the basis of creating profit from the land is lacking. The value of the land as an asset will head toward zero or negative in terms of capitalized value when management fees such as those for cleaning and weeding are considered. If so, the evaluation of "market value" based on the physical form of the land alone is an interpretation that restores the original intent of local tax and is very unlikely to be suitable. There is scope to interpret that the levying of fixed assets tax and inheritance tax, taking into account the profit value that also accounts for the difficulties of rights adjustment, should be how the inherent market value is determined. Landholding tax in excess of the value fosters land immobilization and the

\footnotetext{
${ }^{8}$ According to the teachings of real estate appraisers, Haruki Hirasawa and Hiromi Horikawa.
} 
renunciation of inheritance, thereby accelerating the ruination of our national territory.

When there is a period of rising land prices, capital gains tax has the effect of freezing land transactions (when there are expectations that the price of land will rise, it is beneficial to postpone sales so that transactions are put on hold on the basis that profit will accrue by deferring the payment of the capital gains tax on land). The levying of a land capital gains tax (a tax levied at a high tax rate on the sale price minus the acquisition price, further deducting the added value formation for the owner, and the annual landholding tax, levied on the market price minus the acquisition price multiplied by the interest rate. The profit from the deferred payment of land transfer tax is offset, so it promotes the effective use and liquidation of land) is a preferential tax method to promote the effective utilization of land that removes the adverse effect of land speculation and greatly increases the liquidity of land. ${ }^{9}$ However, even in this case, there must be a purchaser, and the market value after deducting the cost for rights adjustment needs to be positive to enable selling. Selling and effective utilization of land can be difficult depending on the cost to adjust rights.

This is to say nothing of the case where a fixed assets tax is levied, shrinking the profit to the extent that the market value accounting for the cost of reconciling the rights to make use possible falls further with the likelihood of incurring an unrealized loss when the effective present price is below the acquisition price. Apart from the large possibility of an increase in the abandonment of inherited land with consolidation of ineffective land use and the obstruction to effective utilization, this would not appropriately resolve the co-ownership issue at the time of inheritance and also promote the emergence of land with unknown ownership and land that remains unregistered.

\subsubsection{Building Tax}

The optimum tax rate for holding tax in relation to buildings and fixed assets tax in particular should in essence be zero. Tax on buildings is always a hindrance to the effective utilization of land by obstructing building investment, so the tax itself is harmful. However, a very large portion of fixed asset tax applies to the buildings compared to the land. ${ }^{10}$

Moreover, in evaluations of buildings, the ones that use safe methods of construction with resistance to earthquakes and high environmental performance are appraised with high amounts, giving favorable treatment, so to speak, to low

\footnotetext{
${ }^{9}$ Fukui (1997), Iwata (1977), Iwata et al. (1992) pages 183 to 208.

${ }^{10}$ According to materials from the Ministry of Internal Affairs and Communications, revenue from land fixed assets tax accounted for 16.4\% (3374 billion yen) and revenue from fixed assets tax on buildings accounted for $17.7 \%$ (35,684 billion yen) of total revenues from municipalities tax in FY2013.
} 
efficient buildings. It is no exaggeration to state that the fixed assets tax on buildings is a tax system that encourages cheap structures contrary to the promotion of the effective utilization of land. ${ }^{11}$

However, for buildings with negative externalities such as vacant premises that have a negative impact on the nearby environment and buildings with inadequate earthquake resistance and low energy efficiency, levying building holding tax in line with the level of such negative externalities can be considered reasonable in respect of charges under Pigouvian tax. Nevertheless, for buildings without such elements, the levying of building holding tax is increasingly disadvantageous for land use and obstructs investment and ownership.

Thus, it fosters the emergence of land with unknown ownership and is an obstacle to the effective utilization of land.

Furthermore, the evaluation of fixed assets tax on buildings in Japan is conducted using a unique method referred to as the reconstruction cost method. This is a complex and bizarre method for determining the appraisal value that assumes reconstruction using the same method of construction and materials as when the building was new to calculate the construction costs, even if many years have passed since such buildings were built, with accrued depreciation from when the building was built. The method and the materials of construction are essentially different from the method of construction and the materials for the building that would be the most effective utilization at the time of evaluation given the progress that has been made in construction technologies and new preferred methods of construction and materials. However, since no one who would actually build using old materials and methods of construction is likely to be around, the cost of construction using difficult to procure materials and old methods will always be much more expensive than the cost of a new build. As long as evaluations for the reconstruction cost method are based on this strange manner of thinking, the starting point for the appraisal value will be expensive compared to the cost of a new construction and to the acquisition price. Consequently, there is a tendency for the evaluation to be higher than the actual market value of the building corresponding to the years of deterioration. Owing to this gap, the acquisition of old buildings is disadvantageous in terms of tax and reduces the evaluation of the building in the market. It is also an obstacle to the liquidity of existing homes. In the case of inadequate marketability, vacant premises tend to emerge, and negative externalities on buildings tend to appear even for buildings with actual residents. When there is inheritance of such buildings, the rights become increasingly intricate and the problem of land with unknown ownership is exacerbated. The problem of vacant premises and the problem of land with unknown ownership are therefore sustained problems.

In addition to being disadvantageous for building investment and the effective utilization of land, the fixed assets tax on buildings and the over-valuation of buildings through the reconstruction cost method substantially increase the tax

\footnotetext{
${ }^{11}$ Fukui (2016).
} 
cost, which not only creates unnecessary administrative costs but also obstructs investment in and utilization of buildings.

Further, although there is depreciation of land with a building when being assessed for inheritance tax, it is beneficial to retain even those buildings that are subject to negative externalities such as low efficiency in the usage value or dangers to the vicinity, such as fire and environmental degradation, for tax avoidance. Therefore, even when demolishing and converting the land to a new use or converting it to a vacant land lot without negative externalities is thought to be the reasonable option for society and for the land owner, this is artificially obstructed.

Fixed assets tax constrains general investment in buildings including superior ones and obstructs the effective utilization of land. Furthermore, it is inconsistent even for large buildings with poor quality negative externalities by constraining disposal. At the end of the day, the Japanese tax system lacks integrity and consistency for land use and policy-driven objectives.

\subsection{Titling System, Real Estate Registration Tax, Circulation Tax, and Land Liquidity}

As noted above, Japan's titling is not a rights transfer requirement but a perfection requirement. Since there is also no titling obligation, it becomes difficult to record the title if there is little actual benefit for immediate tiling even when inherited or traded because of the difficulty in generating adequate profit or the low risk of double trades. However, this does not mean it is disadvantageous for the owner. Conversely, registration is not available online and the procedures are also complicated, so the general course of events is to request the services of a specialist (e.g., a judicial scrivener), which causes a burden for the applicant of both cost and time. In addition, the burden of the real estate registration tax is always a constraint on the transfer of ownership itself, and the corresponding transaction costs reduce the liquidity of land to that extent.

Furthermore, in Japan, the titling procedures are strict, and it is difficult to imagine that anyone but the true owner is registered as the title deed holder. Therefore, there has been a high probability that the registered title deed holder was the true owner at least at some point of time in the past.

The problem is that the search for the true owner beyond the registered title deed holder tends to become difficult because of factors such as successive inheritances. The title does not accurately reflect the transfer of the relationship of rights that stem from the true owner. It is often a mere reflection of information at a particular point in time in the past. In addition, the registered information has not been digitized and searching is not easy, so it is hard to use as a database.

Stamp duty, real estate acquisition tax, and other factors are further impediments to the circulation of what was originally low liquid real estate, and the extent to 
which taxes cause a burden on transactions reduces the possibility of effective utilization of land.

Eventually, factors such as the tax and titling systems act as barriers to the transfer of land rights, obscuring the true relationship of rights following the transfer of rights or, at least, the information for the true owner at a particular point of time in the past. Further, the function of public notice from the title is not working properly, and the true owner is difficult to identify.

\subsection{Response Through Land Expropriation for Public Business}

\subsubsection{Imperfect Function of the Expropriation System and Unknown Ruling (Ruling Without Knowing the Owner's Identity)}

Land expropriation is possible for businesses with a highly public nature. ${ }^{12}$ Article 29, paragraph (3) of the Constitution of Japan, states the following: "Private property may be taken for public use upon just compensation therefor." The authority to expropriate property rights in certain circumstances means divestment against the owner's intention is condoned and the representative legal enforcement is prescribed in the Expropriation Act (hereinafter, the "Expropriation Act"). Article 3 of the Expropriation Act lists businesses qualified for expropriation. Essentially, these are the operators of facilities supplied to multiple unidentifiable persons, including roads, embankments, dams, facilities for erosion control, railways, ports, airports, sewerage systems, schools, and libraries in accordance with laws, but the implementing organizations also include private sector companies and Incorporated Educational Institutions. Although the implementing organizations were originally limited to public institutions such as national and local public organizations, operators of housing facilities with 50 or more dwellings per housing estate are also deemed to be qualified expropriation businesses. Thus, it should be noted that private property that is not always used because the owners are unknown is also being granted expropriation rights (Article 30).

Furthermore, Article 20 of the Expropriation Act states that to be granted approval for expropriation, there is a requirement that the undertaking for public

\footnotetext{
${ }^{12}$ Fukui (2012), pages 110 to 111 , positions the land expropriation system as a transaction cost measure. Fukui (1998a) suggests the improvement in benefits to multiple residents as well as the maximization of the aggregate amount, time cost savings, and business costs savings, particularly in relation to the requirements of items (iii) and (iv) of Article 20 of the Expropriation Act. Fukui (1998b) criticizes the so-called illegal inheritance theory that allows for disputes against illegal certified projects through the expropriation ruling that takes account of the intent of the expropriation system for quick legal confirmation of the business and the intent of the Administrative Case Litigation Act.
} 
interest (i.e., business operator) is any of the businesses listed in Article 3 of the Act (Article 20, item (i)); the expropriator is a person who has sufficient intention and capacity (Article 20, item (ii)); the undertaking for public interest plan contributes to appropriate and reasonable use of land (Article 20, item (iii)); and expropriation or use of land is necessary for the public interest (Article 20, item (iv)). Of particular importance are the requirements in items (iii) and (iv) for the need to be in the public interest and for the fact that it is appropriate and reasonable use of land. With regard to the requirement in item (iii), as a result of the trade-off between the public profit that should be gained through the provision of the expropriated land for business and the lost profit that this causes, this is permitted under the interpretation of an established court precedent if the former is more beneficial than the latter. ${ }^{13}$

In light of the fact that the Expropriation Act is the implementation act for the Constitution of Japan for the protection of property rights, at least as an intent of the legislators, the concept of "public use" in Article 29, paragraph (3) of the Constitution of Japan, is embodied through the requirements of Article 20, items (iii) and (iv) of the Expropriation Act. Thus, two points can be anticipated. First, there is no issue if the implementing organization is in the private sector and the principle is that the business is provided to multiple unidentifiable persons (A). Second, the profit derived from the business exceeds the profits that are lost (B).

The former justifies the sacrifice of the property rights of a few identified landowners, and this cannot be considered fair if it entails only the profit of a few identified persons; this is the basis of the intent reflected in Article 14 of the Constitution of Japan. The latter is also a standard for efficiency premised on the economic freedom assumed by the Constitution of Japan.

These two are also two large norms in economics. From this perspective as well, the approach to the protection of property rights under the Constitution of Japan and the Expropriation Act can both be seen as friendly for economics. ${ }^{14}$

The Expropriation Act's undertakings for public interest are determined by the Minister of Land, Infrastructure, Transport, and Tourism or a prefectural governor according to the scale of the business, etc., but in recent years, much of the administration of undertakings for public interest by the Minister of Land, Infrastructure, Transport, and Tourism have been transferred to the control of regional area departments and bureaus as part of the rights of regional areas. As part of the research activities of the "Working Group on Land with Unknown Ownership," the three-party joint group at which the author is a deputy chairperson, with Chairperson Masaaki Iwasaki and committee members Junji Annen, Katushiko Itagaki, and Shuhei Yoshida, we conducted interviews of multiple trustworthy persons responsible $^{15}$ for the practice of site compensation and expropriation in August 2017 concerning the practice of land expropriation and site acquisition circumstances

\footnotetext{
${ }^{13}$ Tokyo High Court ruling July 19, 2012 (Supreme Court HP), etc.

${ }^{14}$ Fukui (2012) pages 92 to 94.

${ }^{15}$ To avoid any trouble to the relevant party even in the worst case, the author refrains from mentioning specific organizations and names at the present point in time.
} 
(hereinafter, "expropriation in practice interviews"). These indicated that in the past, the Minister's undertakings for public interest were only handled by the Minister of Land, Infrastructure, Transport, and Tourism and the interpretation and operation were at least unified in relation to matters handled by the Minister. However, at present, the materials required for each department and bureau when applying for the approval of undertakings for public interest are the interpretation of the requirements under Article 20, items (iii) and (iv), and there is disparity in matters such as the period required for prior administrative instructions.

The disparity among prefectures is even greater, and there are not necessarily many people who can accurately give direction concerning the legal interpretation and operations with adequate confidence, owing to circumstances such as the lack of experience of the responsible person and the virtual absence of expropriation incidents at departments and bureaus as well as prefectures. When finding a person responsible who had no experience, there was confusion about judging the requirements on whether something could be seen as an undertaking for public interest and a long time could pass without direction. ${ }^{16}$

The Expropriation Act also keeps a close watch on the reduction of procedural costs. Even if the name and address of the land owner, etc. are unknown, where "those who cannot be identified by the expropriator, if the expropriator was not negligent in being unable to do so," the information need not be included in the application documents for the ruling (Article 40, paragraph (2) of the Expropriation Act), but there is a requirement to attach proof of no negligence to the application (Article 17, item (ii) of the Ordinance for Enforcement of the Act).

Although not a law or ordinance, the Ministry of Land, Infrastructure, Transport, and Tourism Policy Bureau's "Guidelines for investigating beneficiaries pertaining to applications for unknown rulings" (dated May 23, 2014; hereinafter, the "Guidelines") refer to the ordinary scope of investigation in accordance with matters such as title, certificate of residence, family register, and the fixed asset tax ledger as an example and indicate guidelines for such identification documents. Even when deciding on expropriation, the expropriation committee may make a determination if it is clear that the name and address of the owner, etc. cannot be ascertained (Article 48, paragraph (4) and Article 49, paragraph (2) of the Expropriation Act).

\footnotetext{
${ }^{16}$ The author himself worked at the Ministry of Construction, Planning Bureau, General Affairs Division from 1981 to 1983 as the person responsible for matters such as the interpretation, operation, and litigation of the Expropriation Act. At the time, the practice was for only this Ministry to handle undertakings for public interest by the Minister. Previous expropriator hearings occurred, in principle, only once, and it took roughly three months from the initial discussion until the real application. Interpretation operations were also discussed at the division meetings once a week. Precedents and past administrative examples concerning various questions and inquiries from multiple sources nationwide concerning the interpretation of the Expropriation Act, operations, and loss compensation were thoroughly investigated, and there was swift and accurate unified interpretation under the final judgment of the Assistant Director at the time. Even in relation to undertakings for public interest according to the Minister and even if the person responsible was different, there was a unified approach to the operations, with careful attention paid to ensure the requirements under Article 20, items (iii) and (iv), in particular, did not vary greatly.
} 
The Guidelines state the following: "The expropriation committee's level of investigation rights is at the same level as would be required by the expropriator and spending excessive effort and time with a coercive detailed investigation would not be welcome even from the intent of the Expropriation Act. Therefore, the expropriation committee shall mainly confirm if the investigation by the expropriator was appropriate, and shall be required to quickly issue a conclusion if approved as appropriate." Rulings in line with these types of procedures are referred to as unknown determination.

Further, the Expropriation Act also keeps watch to ensure that the ownership of expropriated land is certainly transferred to the expropriator through the expropriation of land and that such legal effect is quickly stabilized. It clearly separates matters that should be determined by parts concerning the efficacy of the ruling, for example, the "area of the land" to be expropriated (Article 48, paragraph (1), item (i) of the Expropriation Act), the time of the acquisition of rights (Article 48, paragraph (1), item (iii) of the Act), time limit for vacation (Article 49, paragraph (1), item (ii) of the Act)), and the "compensation for loss" (Article 49, paragraph (1), items (i) and (ii)).

Although the former can be contested as revocation litigation using administrative litigation, the latter is not recognized as a dispute under administrative litigation. Instead of the expropriation committee being the administrative agency, the action must be filed by the relevant party who is the applicant for the determination and the expropriator who will pay the loss compensation if disputed by the person harmed by the expropriation (Article 133, paragraphs (1) and (3) of the Expropriation Act).

Conversely, Article 48, paragraph (4) of the Expropriation Act, which is the basis provision for the unknown ruling, provides "The expropriation committee must make a determination on the matter set forth in paragraph (1), item (ii) (author's note, compensation for loss) ... specifying the name and address of the landowners ... to receive the relevant compensation; provided, however, that if the name and address of the landowners ... cannot be ascertained, this does not apply to the relevant matter." Thus, the name and address of the owner, etc. are effectively clarified as a ruling concerning loss compensation for the recipient of the loss compensation, and even in the case of a legal dispute, it will not be administrative litigation but subject to the concern of loss compensation for relevant party litigation (Article 133, paragraphs (2) and (3) of the Expropriation Act). Therefore, the dispute must be fought between the person harmed by the expropriation and the expropriator.

That is, even if the expropriator or the expropriation committee were to make a mistake concerning the true landowner not in error but in bad faith, it would only be in relation to whom the loss compensation is to be paid and the true owner would request the expropriator that the legitimate loss compensation should be paid to him or her as the counterparty, which should resolve the relevant party litigation. In other words, as long as one is excluded from being subject to revocation litigation, owner error or deficiencies in the search for an unknown owner will not be a reason for 
revocation. Owner error, regardless of the level of such error or bad faith, has absolutely no impact on the efficacy of the ruling. ${ }^{17}$

Furthermore, even for a trial involving a claim for loss compensation, matters that should be settled will, at least in light of the loss compensation prescribed in the Expropriation Act, be the amount that requires liquidation when there is excess or deficiency compared with the true amount of loss compensation anticipated by law. There will also be no impact on the conclusion of the judgment regarding the level of effort put into the search for the unknown owner of the land in accordance with the determination proceedings for unknown ownership by the expropriation committee or the application of the expropriator's ruling. It is only natural that there would be no reason for a legal interpretation that could have an impact.

Therefore, even from the structure of the Expropriation Act, the owner's payment would only have the meaning of being the payee for the loss compensation amount, so this is not anticipated to incur an enormous amount of time and effort. Although there is no security measure in terms of the administration of justice, a legal duty of the expropriator and the expropriation committee is the requirement that the expropriator should search for the name and address of the landowner to the extent that there is no error while the expropriation committee should mention the name and address of the landowner if identifiable in the ruling documents. However, such error has absolutely no impact on the legal efficacy of the ownership transfer to the expropriator through expropriation, and the problem of the payee for the loss compensation amount is anticipated to be a dispute only with a separate relevant party. Thus, this is the extent to which the Expropriation Act intends the quick stabilization of the efficacy of expropriation once it has occurred regardless of the name and address of the landowner.

Meanwhile, according to the interviews of expropriation practice, the actual administrative instructions of the expropriation committee were not limited to matters mentioned in the Guidelines, and there were requirements for onsite investigations and questioning of local residents for a person's new address not only in Japan but also overseas and in the case of a foreign owner, a requirement to identify and confirm the person. Specifically, there were many examples of extremely excessive operations such as situations wherein there were ongoing requirements to search for the name and address of the owner that were gradually extended without specifying the extent of the search operation. Such operations were often conducted on an intuitive basis without legal arguments of confirmation or safety.

This can be attributed to the person responsible at the prefecture and to the chairperson of the expropriation committee, in addition to committee members who do not adequately understand the intent to which the Expropriation Act is a legislation for the protection of property rights under Article 29 of the Constitution of Japan by way of "promoting the public interest taking into account private

\footnotetext{
${ }^{17}$ On this point, during the period when the author was the person responsible for the Expropriation Act, it was also the established interpretation operation for the relevant bureau of the Ministry of Construction.
} 
property, thereby contributing to the appropriate and reasonable use of national territory" (Article 1 of the Expropriation Act) in circumstances that have not been exhausted.

The time for site acquisition is determined to be the period to institute the public nature of the business. The ongoing extensions of unproductive search operations that are not anticipated under laws and ordinances are not circumstances anticipated by either the Constitution of Japan or the Expropriation Act.

In addition, even if there is a mistake in relation to the owner due to error or bad faith, there is no option for defect or illegality concerning litigation to revoke the expropriation ruling. At most, since it is a matter concerning the person to whom the loss compensation is due, the form of legal dispute for a ruling under the Expropriation Act in relation to such excessive adherence to this type of matter is split into administrative litigation and relevant party litigation. The efficacy of the ruling is a fundamental legal matter that directly relates to the area of land and contravenes the legal intent to enforce settlement.

Furthermore, in subsequent interviews by the author of certain relevant persons in expropriation committees, it was clear that many people with responsibility for administering expropriation believed that a mistaken owner due to error would be a reason for revoking the ruling, if such a situation transpired. It is amazing that many within an expropriation committee, which is a neutral and fair determining body for land expropriation, are likely to have made mistakes in the rudimentary interpretation of the Expropriation Act. This type of thinking should not even be possible. If one were to become the defendant and dispute a ruling, to ensure the "legality" concerning the owner search that can be easily proven at a later trial, despite having no legal basis and being useless or perhaps illegal, it appears the excessive requirement for the owner search that tends to be put on the expropriator by the expropriation committee is the main cause.

At the end of the day, despite accurate means being set under the Expropriation Act, which has very clear requirements to enable site acquisition due to unknown determination for qualified expropriation businesses, errors in legal interpretation and operations as well as the ignorance or lack of understanding of the person responsible raise questions about the inadequate application of the land expropriation system and unknown determination.

\subsection{Steps to Resolve Obstructions to the Effective Utilization of Land with Unknown Ownership Considering the Cause: Prevention and Ex-Post-Facto Measures}

As argued above, there are two issues with the problem of land with unknown ownership. These are the various problems in the legal system that are the cause of the problem and the various problems in the legal system that are bottlenecks for the 
utilization of land with unknown ownership. The former can be considered a problem to be prevented, whereas the latter constitute a problem that requires expost-facto measures. The following presents the ideal policy-driven response, largely from a transaction cost measure perspective for each of these two issues.

\title{
4.6.1 Prevention Policies from the View of What Caused There to be Land with Unknown Ownership
}

\section{Improve the Tilting Ownership and Public Notice Systems}

\author{
Reporting Obligation for the True Owner and Its Public Notification
}

The current titling system does not indicate the name in the body. The registered title deed holder is highly likely to have at least been the true owner at some point in time, but there needs to be information about the current true owner such as the person's heir or the counterparty in the sale-purchase transaction. To this end, titling only provides useless information. Either registration needs to be mandatory or measures need to be introduced that require public notice of the true beneficiary with the establishment of an alternative and simpler public notice system of ownership if registration is to be considerably stricter and burdensome.

In that case, although it does not mean that the title must necessarily be adhered to, the title will become an enormous public resource and the first alternative to improve the scheme to enable simple and rapid registration while also applying the title. If this proves difficult, a system other than registration would be fine, but where there is inheritance or a transfer of ownership, the obligation to report the true beneficiary and broad public notification could be considered a vital policy and a fundamental response to the prevention of the circumstances of successive unknown owners.

\section{Principle of Titling Perfection Requirements}

Note that the principle of titling perfection requirements in the relationship with the situation of unknown ownership is not necessarily harmful, and there is not necessarily a reason for it to be abolished.

\section{Simplification of Titling Procedures}

The complicated and burdensome administrative procedures relating to titling require substantial simplification. Online application should be the principle, and aspects of the application, such as the style and procedures, should be as simple as possible so that even the owner himself or herself can complete the procedure. 
Abolition of Real Estate Registration Tax

As already argued, real estate registration tax is one obstruction to the transfer of land ownership and the effective utilization of land. The tax should be abolished except to the extent of the minimum level of fees to cover costs.

\section{The Public Notice of Land Information Approach}

Title information and, in particular, information concerning the true owner and beneficiary should not only appear in the register but also be made public through notice on a website in real time. In conjunction with this, since a public notice system is to be created, it would simultaneously be desirable, given the ballooning land information and where it is significant for transactions, to have the utmost comprehensive land information database that discloses public land valuation information (e.g., the public notification of land prices, the investigation of land prices, valuation of fixed assets, and inheritance tax assessment) and the aggregation of publicly entitled land use regulation information such as urban planning and building regulations.

In addition, there should be an obligation for landowners and others to submit contact information such as postal address, email address, and telephone number. This should be made as simple a procedure as possible online.

\section{Improve the Tax System that Obstructs the Circulation of Land and Buildings}

The stamp duty on land and building transactions is a substantial obstruction to transactions in the same manner as real estate registration tax and has the effect of obstructing the effective utilization of land. It should, in principle, be abolished or at least substantially reduced. Similarly, real estate acquisition tax should also be abolished or substantially reduced.

\section{Revise Land Tax}

Tighten the Tax Rate on Fixed Assets Tax and Market Value Evaluations

The amount of fixed assets tax on land should be legislated to not exceed around $20 \%$ of the amount calculated by multiplying the market value of land by the land rent equivalent rate. This should be decided by considering measures that do not take away most of the profit from land and that consider the balance with interest income tax.

In addition, the "market value" evaluation of fixed assets tax that in some cases leads to overly expensive operations should, at the very least, maintain the balance 
with the capitalized value in the market while further strengthening the constraints under laws and ordinances with particular attention paid to ensuring that such evaluation does not exceed the market value.

\section{Consider the Cost to Adjust Rights in the Market Value Evaluation}

For land with intricate relationships of rights, as in the case wherein there are multiple beneficiaries making the procedures and usage difficult in practice, there is room for correction of the estimated market value with the cost to adjust such rights. For example, when there is a negative value after subtracting the costs to reconcile the rights from the market value, there is a certain rationale for a tax exemption.

\section{Introduce Land Capital Gains Tax and Unrealized Profit Interest Tax}

Land taxes that can ultimately increase the liquidity of land to the highest while restraining the effect of a freeze on land transactions regardless of the change in the price of land are land capital gains tax together with unrealized profit interest tax. ${ }^{18}$ These tax systems should be introduced in future, and there should be radical revision of the land tax system including land transfer income tax. At that time, the fixed assets tax should be a tax on the acquisition price of the land in accordance with the benefit derived from administrative services and infrastructure. Unrealized profit interest tax rate is collected separately against the market value minus the acquisition price every year, but the fixed assets tax rate needs to be much smaller than the unrealized profit interest tax rate. ${ }^{19}$

In any event, a high rate of fixed asset tax not corresponding to the benefits, such as nearby public service and public welfare facilities, is harmful because it tends to obstruct the effective use of land and fosters the condition of unknown ownership.

The overall land tax system needs to be revised with transformative changes, taking economics knowledge into account to find an appropriate balance.

\footnotetext{
${ }^{18}$ There is still no alternative to the land capital gains tax scheme indicated by Iwata (1977), Iwata et al. (1992), and the neutral tax scheme at the time of sale with virtually the same effect indicted by Hatta (1988), and this is a tax system that gives ultimate priority to promoting the effective utilization of land with virtually no side effects. The above documents by Iwata already provide proof that there is no reason for the assertion that land transfer tax should be reduced and land ownership tax increased to promote the effective utilization of land as was often seen in the past.

${ }^{19}$ Iwata et al. (1992) from page 214. This is because of the need to increase the tax burden on landowners with large unrealized profits to offset the freeze effect.
} 


\section{Correction of Distortion in Inheritance Tax Assessment}

The reduction in evaluation for a land lot with a building and for a house for rent in the land evaluation when calculating inheritance tax distorts the neutrality concerning land use and leads to excess investment in buildings while promoting inferior buildings, thereby obstructing the effective utilization of land. This type of distortion obstructs appropriate transactions and further accelerates the situation of land with unknown ownership. There should be the same land evaluation regardless of the presence of a building on the land or whether the house is for rent, and the inheritance tax assessment should be applied equally so that there is no harmful bias toward land use in the tax system.

\section{Revise Fixed Assets Tax on Buildings}

\section{Abolition of Fixed Assets Tax on Building that Do Not Cause Negative Externalities}

The fixed assets tax on buildings only leads to a constraint on investments in safe and comfortable buildings, the effective utilization of land, and the circulation of land as well as harming the incentive to clarify the relationship of rights. It has no merit and many demerits. Even the benefits from the public service and public welfare facilities that increase the utility of land only belong to the land, so there is no reason to apply the fixed assets tax on buildings from this perspective either. It is no exaggeration to call it an example of a harmful useless tax system, and, in principle, it should be completely abolished.

However, buildings with inferior earthquake resistance, fire resistance properties, and inferior environmental performance as well as vacant house and houses overflowing with garbage cause negative externalities to the neighborhood, so taxing such buildings can be rationalized as a Pigouvian tax that internalizes the negative externalities corresponding to the level of the negative impact on the neighborhood.

\section{Abolish the Reconstruction Cost Method for Evaluating the Fixed Assets Tax on Buildings and Change to an Acquisition Price-Based Method}

Even if the fixed assets tax on buildings persists until it is abolished, the evaluation method should abolish the reconstruction cost method and shift to an acquisition price-based method. That is, in principle, the method should be corrected to one that is based on the price at the time of purchase or contract with accumulated depreciation. In addition, there is no rationale for the current method that has a lower limit for depreciation of up to $20 \%$ of the reconstruction price. As the phrase states, to reflect "market value," depreciation should be allowed to go below $20 \%$.

It is self-evident that the reconstruction cost method will tend to result in divergence from the actual market price, and this most likely contradicts the original 
principle of the Local Tax Act to tax "market value." It is no exaggeration to state that this evaluation method could be considered close to illegal. Since the reconstruction price is virtually always higher than the actual building value, it is convenient for securing tax revenue but deviates from the intent of holdings tax that taxes actual profit and creates an excessive burden on the target taxpayer. Further, by making the holding of old buildings generally more disadvantageous than new constructions, it prevents the circulation of existing homes, obstructs the liquidation of land and the effective utilization of land, and fosters land with unknown ownership.

Essentially, the fixed assets tax on buildings should be abolished. However, during the foreseeable future when buildings with the fixed assets tax continue, the method of evaluation should be changed to one that is based on the price pertaining to the purchase or contract at the time of acquisition with depreciation corresponding to the evaluation in the market. However, even in this case, factors that are superior and that reduce the negative externalities on the neighborhood, e.g., investments contributing to the improvement of safety, the environment, and comfort, surpassing the lower limit prescribed by the Building Standards Act, should mean that the increase in the amount over the acquisition price required to form added value in the building is deductible.

In addition, since the reconstruction cost method is complicated and burdensome, the tax bureaus of many local government bodies allocate specialist employees to that task alone, which incurs enormous administrative costs. Thus, there is also no reason from the perspective of eliminating waste and improving administrative efficiency.

Note that essentially, buildings are property with utility when combined with land, and it is difficult to calculate the capitalized value for a standalone building. Were the value that belongs to the building to be calculated, the original building price would need to be calculated by deducting the market price for the land as a vacant block of land from the market price of the building together with the land. When calculating the price using the method based on the acquisition price, the calculation needs to be balanced with this price.

\section{Improve the Co-ownership System and Inheritance System Under the Civil Code: Restrict the State of Co-ownership}

The state of co-ownership of property rights is fundamentally undesirable from the perspective of increasing the cost to adjust rights and transaction costs. The management of land and building is much more complicated than for personal property, so the costs of rights adjustment need to be completely reduced even just from the perspective of the transaction costs. Furthermore, land and buildings cannot exist solely without impact on others, so real estate should be considered to have a certain level of positive or negative externality. Therefore, the permission of an unlimited state of co-ownership with the same property rights, akin to personal property without externalities, is, as a principle, an inefficient ownership system that does 
not take account of the constraints inherent in property rights. Although the current Civil Code is also not necessarily favorable toward co-ownership, its systemic collateral is not exhaustive.

Since the state of co-ownership increases transaction costs and is the original cause of unknown ownership of land and buildings, there should be a regulation of co-ownership by two or more owners after a certain grace period with sole ownership as the principle.

Similarly, even for schemes of co-ownership of land through unit owners, there is no rationale from the perspective of transaction cost measures. Hence, in future, condominiums should be prohibited from allowing the legal state of unit owner condominiums. Permits should only allow for sole owners of a wing or of an entire complex, and it would be appropriate for joint housing to only permit rental condominiums.

Furthermore, for inherited lands and building, the permission for co-ownership before the establishment of split discussion and the legal approval of such co-ownership through split discussion or wills serve to increase the transaction costs for adjustment between owners concerning disposition and management and are the main cause for exacerbating the subsequent problem of the unknown ownership of land.

Therefore, in essence, the co-ownership of land and buildings through a will should be prohibited, and even in the case of a legal inheritance, there should simultaneously be a treatment so that there is sole inheritance of the land and building with a certain automatic priority. The adjustment of inherited property between heirs should be through the distribution of cash on selling the property or liquidation through cash to persons not inheriting the land and buildings.

\subsubsection{Promote the Use of Land with Unknown Ownership}

\section{Unify the Operation of the Land Expropriation System and Aggregate the Implementation Organization}

Qualified expropriation businesses ultimately deposit loss compensation amounts without knowing the owner in accordance with the system of unknown determination for unknown ownership regardless of whether the expropriator is public or private and enable the transfer of rights to the expropriator through expropriation. However, as already noted, expropriator organizations are not necessarily accustomed to expropriation in practice. Owing to the lack of examples because of the small number of organizational units responsible for the administration of expropriation rulings and undertakings for public interest, there are few employees skilled in operations relating to the Expropriation Act on both the application and trial sides. In addition, there has not been a thorough application of a unified strict legal interpretation or operations as an act for enforcement of the Constitution of Japan. As a result, the expropriator, the agency certifying the project, and the expropriation 
committee face considerably uncertain hurdles in obtaining an approval for the undertaking of an operation or unknown determination.

Therefore, expropriators, agencies certifying the project, and the expropriation committee should be reviewed to enable the pursuit of the benefits of scale when processing administration such as during the aggregation of operations into certain large organizations. Operations with extremely powerful authority, such as practical expropriation, must aim at being based on strict monocracy principles and must avoid encompassing a relationship with local political interests while avoiding a move toward excessive separatism.

Along with this, the matters that should be noted when unifying matters such as the operations under the land expropriation system should be further documented and made official by the Ministry of Land, Infrastructure, Transport, and Tourism with an aim to further enlighten and ensure common awareness.

\section{Improve Unknown Determination}

As already discussed, the current operations concerning unknown determination under the Expropriation Act tend to require search obligations placed on the expropriator that are in excess of the legal expectations. Even for business with high levels of community and public interest, there is a tendency to obstruct such realization when it includes land with intricate relationships of rights.

Therefore, for the time being, the content of the current Guidelines should not stop at being administrative guidance but should be positioned as the laws and ordinance entrusted under law.

In addition, when there is an obligation for registration and the public notice of true ownership, if there is no reply to a notice sent by post to the contact point, for example, to the registered address, or if the notice is returned to the sender because the addressee is unknown, the expropriator shall take the position that he or she is not mistaken in being unable to learn the name and address of the owner. There should be no obligation for further searches, and the expropriation committee should have no legal requirement for additional searches.

\section{Implementation of a Ruling Scheme for the Disposal and Use of Land for Private Sector Businesses}

Even for private sector businesses and businesses that are not qualified for expropriation, where land is necessary for the business, it is not appropriate for society if this comes to a standstill because of the difficulty of reconciling rights with landowners. 


\section{Schemes Where a Business Is of a Certain Public Nature}

To be positioned as a business that directly qualifies for expropriation under the Expropriation Act, the business must qualify as "may be taken for public use" (Article 29, paragraph (3) of the Constitution of Japan). To achieve this, it is necessary to provide certain unidentified multiple uses (A) at the same time as ensuring the profit gained by the business exceeds the loss of profit (B). However, there are many private businesses that, although not necessarily providing unidentified multiple uses, would generate profit by providing the land to such business in excess of the profit that would be lost through such action.

The concept of "may be taken for public use" in the Constitution of Japan as a principle anticipates the case of "use" contrary to the owner's intention, so strictly speaking, if all owners are unknown and such intent cannot be confirmed, it will not necessarily be contrary to the relevant parties' intent. Where expropriation is necessary even if there is a determination of unknown, if the requirements of both $\mathrm{A}$ and $\mathrm{B}$ are met, the definitive transfer of ownership to the expropriator can be rationalized even if the intent of the landowner cannot be confirmed.

However, in the case that B is applicable but $\mathrm{A}$ is not, it is desirable from a socioeconomic perspective for the business to be realized. Further, where the action would be contrary to the intent of the owner, it is only natural that there needs to be direct expropriation procedures, but if the owner is unknown and it is difficult to confirm such intent, the interpretation should be that it is definitely not in contravention of the Article 29, paragraph (3) of the Constitution of Japan in that certain usage rights are set under a certain public ruling for such business.

From this perspective, the current investigation of systems ${ }^{20}$ relating to land with unknown ownership by the Ministry of Land, Infrastructure, Transport, and Tourism granting a certain period of usage rights for temporary facilities, regardless of whether by a public or private entity, that can be restored to their original state as public type businesses that invest in the welfare of local residents is rational.

Note that as a problem of limitations in Article 29, paragraph (3) of the Constitution of Japan, as long as the investigation is made from the perspective of business necessity, were there less factors of A (unidentified multiple uses) and only for a few identified private uses, if $\mathrm{B}$ is met with a use that is desirable from a socioeconomic perspective, and, in addition, if there is a high probability that the true owner would profit from the rental or sale to provide such use, even when it makes sense to estimate that one wants to gain transactional profit from the rental or sale for such business use as the intent of the relevant party, the transaction may not happen and the land use may stall. Actual problems of this type cannot be resolved if it is considered to be a mere problem of positive externalities and restriction of private rights for public goods.

\footnotetext{
${ }^{20}$ December 5, 2017, Interim summary presented by the special subcommittee of the National Land Council Land Policy Committee (Draft) from page 8.
} 
Scheme of Legal Fiction for the Owner's Intent as a Transaction Costs Measure

As already discussed, the essence of the problem of land with unknown ownership, be it a case where it is hard to apply the unknown determination for the qualified expropriation businesses or a case where it is hard to establish the transaction for private business of the private sector, is a transaction cost problem due to the difficulty of decision-making concerning the types of procedures and management and whether to sell or not or rent out or not without identifying the intention of the land owner because the land in a certain unit necessary for business with an intricate relationship of rights is in a state of shared ownership.

If the land has a sole owner, the decision-making transaction cost is zero, and when there is a buyer who places a higher value on the land than the owner's reservation price, the transfer of ownership or setting of a right of lease will cause the transfer of rights to a person with a high probability of ensuring more efficient land use, so there is no effort required or time cost for decision-making and improvement in efficiency can be easily realized.

However, where there is co-ownership of land, as already discussed, even a decision to rent a property cannot be made without the intent of the majority interest and decision-making needs to be unanimous if the land is to be sold. Thus, even in cases where the names and addresses have been clearly identified, enormous transaction costs are required to obtain agreement of intent between co-owners.

Although these costs for decision-making cannot be avoided even if the relevant parties are identified, when directly confronted with the problem of land with unknown ownership, the transaction costs for decision-making become even more astronomical in the case of a lack of clarity concerning the relevant party being the owner.

Therefore, as a measure to reduce the transaction costs pertaining to the decisionmaking of the landowner being the relevant owner, building a new scheme regardless of the public nature would create a more essential solution than investigating the loosening of the bond of certain businesses in the pursuit of the limitation of the curse of public nature.

In terms of the unanimous principle concerning common property procedures in the Civil Code, the systems for reconstructing condominiums and selling their lots have already breached the legal system. The land for condominiums is co-owned, and the dwelling part takes a troublesome form of rights that involves substantially complicated decision-making by the unit owners. In the case of detached houses and rental condominiums of sole ownership, in principle, repairs and refurbishments and all acts such as demolition and reconstruction and sales of vacant plots of land are certainly easy because they are only subject to the owner's intent.

By contrast, in the past, condominiums were treated the same as common property under the Civil Code, and procedures such as reconstruction were not possible without a unanimous decision. After consideration of the unrealistic transaction costs associated with this, the so-called Act on Building Unit Ownership, etc., and the Act on Facilitation of Reconstruction of Condominiums now require 
resolutions for reconstruction and resolutions to sell lots to be determined by $80 \%$ of voting rights, etc. However, in actuality, such a resolution is extremely difficult and even for condominiums that are deteriorating or have inferior earthquake resistance, it is extremely rare for them to be reconstructed or turned into vacant lots. There are very few successful examples of reconstruction even among the stock of condominiums that have suffered enormous deterioration, and many condominiums facing problems persist as inferior buildings because of the difficulties of reconciling rights; there has already been much discussion from multiple practitioners and researchers on the topic. ${ }^{21}$

Nevertheless, the intent of exceptions in the Civil Code for common property procedures for condominiums is no reason to cause public nature to attribute for the neighborhood, such as so-called externalities and public goods. Many owners are relevant parties, and there are many cases of conflicts with mutual interest. Thus, based on the high probability that the requirement for adjustment of rights to be unanimous will increase the transaction costs and distort land use considerably, schemes have been established to allow the agreement of intent, such as reconstruction resolutions, to be reached more easily by the relevant parties as a transaction cost measure to promote private property management procedures. In this sense, the principle of common property procedures pertaining to condominiums is not derived from Article 29, paragraph (3) of the Constitution of Japan.

There will no doubt also be circumstance where future unit owners become unknown because of the progressive deterioration of condominiums. In such cases, a problem similar to the problem of land with unknown ownership will emerge in the form of "the problem of condominiums with unknown unit owners," and many condominiums will likely find it difficult to reach the $80 \%$ vote required for resolutions.

In this sense, the response of loosening the special majority requirements as a substitute for the unanimous principle, similar to the one used for common property procedures in the Civil Code, cannot radically resolve the problem of unknown owners. In essence, true owners exist, but the fact that their intention is not clear is the root of the problem, and as long as this persists, an enormous amount of effort and cost will be incurred in searching for such intent. Since it is unreasonable to provide land to a person who could potentially make effective use of the land who wants to buy it and for the owner to be unable to secure profit on land, it is not an erratic action as a transaction cost measure that a public entity is involved in making legal fiction of the reasonable intent of the owner acting as an agent for the decisionmaking that can infer what is considered to be the essential rationale.

Therefore, where it is not possible to confirm intent because the owner is unknown, including the case where some co-owners are unknown, such intent should be created as legal fiction acting as agent for the decision-making with the establishment of a deposit scheme for the sales proceeds and rental revenues until the

\footnotetext{
${ }^{21}$ See submission included in Asami et al. (2012).
} 
true owner appears. In such cases, it will be necessary for the agent to not only use the land but also to definitely conduct the acts of disposal such as its sale.

\section{Abolition of the Unanimous Principle for Common Property Procedures: Simplify the State of Shared Ownership Resolution}

The argument in section "Implementation of a Ruling Scheme for the Disposal and Use of Land for Private Sector Businesses" concerning the scheme of legal fiction of the owner's intent as a transaction cost measure is a more fundamental measure, but the current provisions for the management of common property in the Civil Code also increase the transaction costs and need to be improved. At the very least, it is not desirable to constrain the use of land and buildings. Furthermore, in certain circumstances, as long as there are externalities because of land use, there is no rationale to the original principle of unanimity under the Civil Code for common property procedures.

It should be made possible to permit the disposal of land and buildings with a majority or a special majority of about two-thirds of their entire value. This type of scheme is likely to result in it being easy to resolve a state of shared ownership. This is also the direction in line with the original intent of the Civil Code.

\subsubsection{Land Not Liquidated Even If It Minimizes Transaction Costs}

\section{Thorough Tax Exemption for the Fixed Assets Tax: Constraints on Investment in Public Service and Public Welfare Facilities}

Even if the rights adjustment costs are minimized through the aforementioned policies, for land that does not have a high value of use, indicating little possibility of liquidation, and that is difficult for even the owner to use, there should be thorough tax exemptions for the fixed assets tax.

Even from the perspective of securing the financial resources to improve public service and public welfare facilities and administrative services, which is the original function of the fixed assets tax, it is difficult to rationalize a certain public investment in the vicinity of the land even if the market value does not become positive. Consequently, nominal investment to increase the value of use of land in the vicinity of the tax-exempt land is nothing but a sunk cost, and this type of investment should be constrained. 


\section{System for Renouncing Ownership and Inheritance in Relation to Land and Building}

Land with little usage value should be levied with a certain management fee, and it should be possible to renounce ownership for public management. The restraint on the use of land of owners without incentive to use the land has meaning as a measure for negative externalities of land use.

Similarly, apart from the current renunciation of inheritance (renunciation and qualified acceptance) for land without usage value, there is scope to establish a system of renunciation of sole inheritance independent from other inherited property. In this case, as with the renunciation of ownership, a certain management fee should be collected and there should be public management.

\section{Non-participation in Land with Little Usage Value}

Even when rights adjustment costs are priced in and without any reason for belonging to public management, land with little usage value signifies that it is not suitable for public participation. Land without value is a waste of public funds, so there should be no public spending nor participation of administrative employees regardless of whether it is nominally for gathering information, assistance, or business.

Measures for land with unknown ownership should only be targeted at land that has a certain possibility for effective utilization.

\subsection{The Connection Between Urban Aggregation and the Problem of Land with Unknown Ownership}

The delineation system for urban planning, Location Normalization Plan, and residential guidance zone systems are all aimed at improving the efficiency of investment in infrastructure through urban aggregation. However, in recent years, a progressively aging population and declining birth rates have meant that the concentration of various functions for the traditional population has been focused on urban centers, and the image of the city on which the traditional form of urban policies for urban expansion and the urban sprawl have been based is being challenged to transform. Thus, many areas will be forced to assume urban images that are scheduled to contract.

Essentially, each type of policy for urban aggregation and compact city policies, for example, will lead to a polarization of preservation and application of land in areas on the outskirts of cities and in rural areas according to their potential use. However, as already discussed, if there is a transformation to a more appropriate land transfer tax and fixed assets tax, the negative externalities of land use will be restrained and function as automatic stability mechanisms to drive fair ways of 
spending tax, without relying on invocations of very ineffective rights of land use regulation that will meet with strong political resistance.

A tax system and investment cycle that reinvests within the scope of revenues from land fixed assets tax and to the extent of increasing the land values will achieve an aggregated urban structure that is safer and better for the environment while simultaneously constraining wasteful public investment. This type of reorganization for the urban structure will increase the liquidity for land that is suitable for effective utilization in the center and most likely mitigate the problem of land with unknown ownership. Even if public organizations do not artificially participate at all costs in relation to urban and regional areas, as long as the locations are those that are required and activated naturally regardless of whether the land usage is a public or private entity, it will accelerate the effective utilization of land and foster a positive cycle with positive externalities of land usage in the vicinity.

From this perspective, the local government body that is currently involved in taxing fixed assets tax does not correspond to the benefits or burden for each public service and public welfare facility. It will have a reason to conceptualize the idea of the "local government body" for each facility that should unify tax and investment as a unit. Dealing with the problem of land with unknown ownership will essentially be driven by implementing this type of concept of a local government body, which should allow for a more effective realization.

\section{References}

Asami Y, Fukui H, Yamaguchi M (2012) Rebuilding the condominium: how to prepare for decrepitude (Manshon Tatekae-Roukyuka Ni Dou Sonaeruka). Nippon Hyoron Sha Co., Ltd., Tokyo

Fukui H (1997) Fallacy of land tax theories (I) and (II) (Tochizeiseiron No Gobyu (Jyo), (GE)), No. 7876 and 7877. Zeimukeiri, Tokyo

Fukui H (1998a) Agendas of land expropriation (I) and (II) (Tochishuyouseido No Kadai (1), (2)). Local Autonomy Seminar 37 $(5,6)$

Fukui H (1998b) Transferability of illegal approval of public works by land expropriation act (Tochishuyouhou Niyoru Jigyonintei No Ihousei No Keisho). In: Nishitani T et al. (eds) Realization of policy and administrative law (Seisakujitsugen To Gyoseiho). Yuhikaku Publishing Co., Ltd., Tokyo

Fukui H (1999) Does environmental factors affect evaluation of buildings? (Kankyoyouin Ha Tatemonohyoka Ni Eikyo Suruka). Zeimukeiri, Tokyo, p 8096

Fukui H (2001) Allocation of rights and control of discretion in light of Coase Theorem (Kenri No Haibun - Sairyo No Tosei To Kosu No Teiri). In: Kobayakawa M et al. (eds) Development and change of administrative laws (I)(Gyouseriho No Hatten To Henkaku (Jyo)). Yuhikaku Publishing Co., Ltd., Tokyo

Fukui H (2007) Let's begin law and economics with cases: finding hidden functions of law (Kesu Kara Hajimeyou Ho To Keizaigaku-Hou No Kakureta Kinou Wo Shiru). Nippon Hyoron Sha Co., Ltd., Tokyo

Fukui H (2012) Restructuring administrative laws in face of the failure of market (Shijyo No Shippai Tositeno Gyoseiho No Saikousei). In: Takagi H et al. (eds) For the future of the study of administrative laws (Gyouseihugaku No Mirai Ni Mukete). Yuhikaku Publishing Co., Ltd., Tokyo 
Fukai H (2016) Does the fixed asset tax on buildings have grounds? (Tatemonokoteishisannzei Ni Riyuu Ha Aruka). Zeimukeiri, Tokyo, No. 9495

Fukui H, Yoshida S (eds) (2008) Alternative measures for middle omission registration and transaction of real estate (Chuukanshoryakutoki No Daitaishudan To Fudousantorihiki). Jutaku-Shimpo Inc., Tokyo

Hatta T (1988) Reform of direct Taxes (Chokusetsuzei Kaikaku). Nikkei Inc., Tokyo

Iwata K (1977) Economics of land and housing (Tochi to Jyutaku No Keizaigaku). Nikkei Inc., Tokyo

Iwata K, Kobayashi N, Fukui H (1992) Theory of city and land (Toshi to Tochi No Riron). Gyosei Corporation, Tokyo

Suzuki R (2007) Lecture note on real rights (Fifth edition) (Bukkenho Kougi). Sobunsha, Tokyo

Open Access This chapter is licensed under the terms of the Creative Commons Attribution 4.0 International License (http://creativecommons.org/licenses/by/4.0/), which permits use, sharing, adaptation, distribution and reproduction in any medium or format, as long as you give appropriate credit to the original author(s) and the source, provide a link to the Creative Commons licence and indicate if changes were made.

The images or other third party material in this chapter are included in the chapter's Creative Commons licence, unless indicated otherwise in a credit line to the material. If material is not included in the chapter's Creative Commons licence and your intended use is not permitted by statutory regulation or exceeds the permitted use, you will need to obtain permission directly from the copyright holder. 